\title{
Effect of Storage Conditions on the Sensory Quality, Colour and Texture of Fresh-Cut Minimally Processed Cabbage with the Addition of Ascorbic Acid, Citric Acid and Calcium Chloride
}

\author{
Eleni Manolopoulou ${ }^{1}$, Theodoros Varzakas ${ }^{2^{*}}$ \\ ${ }^{1}$ Department of Plant Production, School of Agricultural Technology, Higher Institute of Kalamata, Kalamata, Greece; ${ }^{2}$ Department \\ of Food Technology, School of Agricultural Technology, Higher Institute of Kalamata, Kalamata, Greece. \\ Email: *theovarzakas@yahoo.gr
}

Received July 20 $0^{\text {th }}, 2011$; revised August $23^{\text {rd }}, 2011$; accepted August $30^{\text {th }}, 2011$.

\begin{abstract}
The aim of this study was to investigate the effect of storage conditions on the sensory quality, colour and texture of fresh-cut cabbage during the addition of ascorbic acid, citric acid and calcium chloride. Ascorbic acid maintained the overall quality for 14 days at $0^{\circ} \mathrm{C}$ and 7 days at $5^{\circ} \mathrm{C}$; no difference, however, was observed regarding browning of cut surface compared to the control sample at both storage temperatures. Calcium chloride maintained the overall quality and cut surface browning for 14 days at both storage temperatures. It was also found that citric acid $1 \%$ can be used for minimally processed cabbage. Soaking with citric acid helped retain the color and increased the overall acceptance and organoleptic quality of fresh cut cabbage; it reduced browning of the cut surface and protected against formation of black specks. Citric acid treatment combined with low temperature storage $\left(0^{\circ} \mathrm{C}\right)$ prolonged the shelf life of minimally processed cabbage for 22 days, time sufficient for acceptable marketing of the product. The lightness of minimally processed cabbage decreased linearly from $70.94 \pm 6$ to $63.8 \pm 8.5-61.3 \pm 8$ units for the chemical treatments during 22 days of storage at $0^{\circ} \mathrm{C}$. Hue angle values during storage time were also significantly influenced by chemical treatments mainly at $0^{\circ} \mathrm{C}$.
\end{abstract}

Keywords: Storage, Sensory Quality, Colour, Texture, Fresh-Cut Minimally Processed Cabbage, Ascorbic Acid, Citric Acid, Calcium Chloride

\section{Introduction}

Minimally processed vegetables have become widely accepted in restaurants, catering services, salad bars and consumer packs for home use.

The primary quality attributes of a fresh-cut vegetable include colour, texture, flavour and odour [1].

Minimally processing operations such as peeling, coring and cutting damage the tissue integrity resulting in cellular decompartmentation. Contact of enzymes and substrates lead to biochemical injuries such as browning, off-flavours and texture breakdown. Enzymatic browning and textural defects reduce product quality and shelf-life $[2,3]$.

Degree of browning depends on phenol content, polyphenol oxidase (PPO) activity [4] and oxygen concentrations.
Brown discolorations in foods are complex because of the large number of secondary reactions that may occur [5].

Various approaches are now applied to limit enzymatic browning such as modified atmosphere [6], chemicals inhibitors and gaseous chlorine dioxide $[7,8]$ or novel decontamination methods such as neutral electrolysed oxidising water [9]. Chemicals exhibit different modes of action on preventing enzymatic browning; the following groups may be used: reducing agents, chelating agents, inorganic salts.

Ascorbic acid is a moderate reducing component, acidic in nature. It forms neutral salts with bases and is water soluble. Ascorbic acid is generally recognized as safe (GRAS) for use in fruits and vegetables [10] and is probably the most widely used. 
Citric acid is the best known chelating agent for use in fruits and vegetables $[11,12]$ and is a phenolase $\mathrm{Cu}$-chelating agent. The inhibition of polyphenol oxides (PPO) was attributed to the chelating action [13]. Citric acid is usually used in combination with other anti-browning agents [14].

Salts of calcium have been tested as anti-browning agents. Van Rensburg and Engelbrecht [15] studied the effect of calcium salts on susceptibility to browning of avocados. Varella et al. [16] proposed the use of minimally processed apples "Fuji" in a treatment with $1 \%$ $\mathrm{CaCl}_{2}$ for 16 days storage at $8^{\circ} \mathrm{C}-10^{\circ} \mathrm{C}$. Kim and Klieber [17] reported that calcium chloride reduce browning in minimally processed Chinese cabbage.

Cabbage is an important member of cruciferous vegetables being also an important dietary vegetable consumed as fresh cut salad or cooked. Recently it was widely marketed as a minimally processed product. Brassica vegetables (cabbage, cauliflower, broccoli, Brussels sprouts, Kale) possess antioxidant and anticarcinogenic properties [18] and a large group of glycosinolates. Their hydrolysis products can protect against cancer [19].

Finally Rinaldi et al. [20] studied the shelf life of minimally processed cabbage stored under controlled atmospehere $(\mathrm{CA})$ and found that $\mathrm{CA}$ did not prolong the shelf life of 10 days at $5^{\circ} \mathrm{C}$. Rinaldi et al. [21] also reported that LDPE packaging was more adequate for fresh-cut cabbage storage.

The objective of this study was to investigate the potential of ascorbic acid, citric acid and calcium chloride, individually, to extend the shelf life and maintain the quality of fresh-cut cabbage.

\section{Materials and Methods}

\subsection{Raw Material and Treatments}

White Cabbage (Brassica oleracea L. var. capitata) var. Bunner harvested in March and April from a farm located in Messinia (Peloponnese, Greece) was minimally processed using the best preparation techniques. The leaves were cut into quarters and then sliced into $3 \mathrm{~cm}$ wide strips with a sharp stainless steel knife sterilized in ethanol. The shredded cabbage was washed for $4 \mathrm{~min}$ in chlorinated $(100 \mathrm{ppm} \mathrm{NaOCl})$ water at $5^{\circ} \mathrm{C}$ (at a solid/ liquid ratio of 1:3) to remove released nutrients. Then the cabbage was rinsed with tap water for 4 min and centrifuged for $1 \mathrm{~min}$ at a speed of $500 \mathrm{rpm}$.

The treatments were conducted in parallel and prepared for the same batch of product. To minimize product heterogeneity, processed cabbage was pooled, mixed and subsequently divided in four equal parts. The first part was imbibed in distilled water and was used as a control. The second, third and fourth parts were imbibed in ascorbic acid, citric acid and calcium chloride solution, respectively.

Imbibition treatments with solutions of ascorbic acid (Serva, Germany), citric acid (Merck, Germany) and calcium chloride (Carlo Erba, Italy) were applied separately for $3 \mathrm{~min}$, after draining. All dipping solutions were made with distilled water at $5^{\circ} \mathrm{C}$ and the concentrations were $1 \%(\mathrm{w} / \mathrm{v})$ at all cases.

$100 \pm 2$ g cabbage slices treated with ascorbic acid, citric acid, calcium chloride or distilled water (control) were placed in clear polystyrene trays $(15.5 \times 22.5 \times 3$ $\mathrm{cm})$ covered with PVC film $(13 \mu \mathrm{m})$ and stored at $0^{\circ} \mathrm{C}$ and $5^{\circ} \mathrm{C}$ and $90 \%$ E.R.H. in darkness.

Mass loss, instrumental texture, instrumental colour, total soluble solids (TSS), visual quality were evaluated at days $0,7,14$ and 22. Six packs (replicates) were prepared for each sampling date and treatment. For mass loss ten packs per treatment were prepared.

Mass loss (\%) was calculated as percentage of the initial mass of each sample using an electronic scale with an accuracy of $\pm 0.01 \mathrm{~g}$. Weighing was carried out in air conditioned area to avoid package condensation.

\subsection{Texture Analysis}

Firmness was evaluated using a Texture Analyser TAXT2i (SMS, UK) with a $100 \mathrm{~N}$ load cell attached. A Kramer shear cell with a five probe attached to the instrument was used. The speed of the probe was set to 1 $\mathrm{mm} \cdot \mathrm{s}^{-1}$. Firmness was evaluated in terms of maximum force (rupture force in $\mathrm{N}$ ) recorded in a typical forcedistance diagram.

\subsection{Colour}

Colour was measured with a Minolta CR-300 chromameter (Minolta Corp. Japan) on CIE L*, a*, b* chromatic space. The degree of browning was analysed in terms of changes in $L^{*}$, and hue angle values $\left(h^{\circ}\right)$.

Total soluble solids (TSS) was measured using a digital refractometer (SR-400) in a $10 \mathrm{~g}$ homogeneous and filtered cabbage pulp sample.

Quality changes (cut surface browning, black speck, microbial spoilage and overall visual acceptance) were evaluated in 6 packs per treatment, by sensory evaluation performed by 6 semi trained panellists using a score system from 1 to 5 (Table 1) with the score of 3 as the cut off for marketing.

\subsection{Statistical Analysis}

The experiment was performed according to a full factorial design (treatments $\times$ storage time) and subjected to an analysis of variance (ANOVA) using the Statgraphics 
Table 1. Estimation of visual quality characteristics of minimally processed cabbage (Adapted from Kim and Klieber, 1997).

\begin{tabular}{|c|c|c|c|c|c|}
\hline \multirow{2}{*}{ Characteristics } & \multicolumn{5}{|c|}{ Score } \\
\hline & 5 & 4 & 3 & 2 & 1 \\
\hline Black speck & None & $\begin{array}{c}\text { Few small specks on } \\
<5 \text { pieces }\end{array}$ & $\begin{array}{l}\text { Some small specks on } \\
<10 \text { pieces }\end{array}$ & $\begin{array}{l}\text { Some large specks on } \\
<20 \text { pieces }\end{array}$ & $\begin{array}{c}\text { Many large specks on } \\
>20 \text { pieces }\end{array}$ \\
\hline Overall visual quality & Very fresh & Fresh & Marketable & Edible non marketable & Non edible. \\
\hline
\end{tabular}

Plus 5.1 (Statpoint Technologies, Inc, VA, USA) statistical software. Mean values were subjected to Fisher's Least Significant Difference test (LSD) at $p=0.05$. This statistical test is liberal with respect to the comparison wise error rate, however, it is powerful for detecting true difference [22]. Data shown in the figures and tables are the mean values of two experimental series since no significant difference between the series was found.

\section{Results and Discussion}

\subsection{Weight Loss}

The multifactor ANOVA indicated that storage temperature, chemical treatments and storage time affected $(p=$ 0.05 ) weight loss. After 22 days at $0^{\circ} \mathrm{C}$ in air, weight loss (Table 2) was similar for the control and the treatments with ascorbic acid and calcium chloride $(2.28 \%-2.81 \%)$. The treatment with citric acid showed significantly higher weight loss $(3.17 \%)$. Similar results were presented at $5^{\circ} \mathrm{C}$. A linear correlation was found between weight loss and storage time $\left(R^{2}=0.985-0.995\right)$.

Leafy vegetables are particularly vulnerable to rapid water loss [23]. The loss in moisture results in a reduction of fresh weight accompanied by the loss of freshness, appearance and texture. The maximum acceptable weight loss of cabbage is $7 \%[23,24]$. In the present study, weight loss was below $7 \%$ at both storage temperatures $\left(0^{\circ} \mathrm{C}, 5^{\circ} \mathrm{C}\right)$.

\subsection{Texture}

Firmness changes of minimal processed cabbage during storage at $0^{\circ} \mathrm{C}$ and $5^{\circ} \mathrm{C}$ depend upon the soaking solution and the time of storage (Figure 1).

The rupture values for minimally processed cabbage treated with different chemicals as well as these of control increased over the 22 days storage period. This increase varied between $2.2 \%-5 \%$ at $0{ }^{\circ} \mathrm{C}$ for the control and the treatments with ascorbic and citric acid. At $5^{\circ} \mathrm{C}$ the increase varied between $6 \%-8 \%$ for the control and treatment with citric acid and $13 \%$ for the treatment with ascorbic acid. Calcium chloride had a greater firming
Table 2. Weight loss of minimal processing cabbage treated with different chemicals after 22 days of storage at $0^{\circ} \mathrm{C}$ and $5^{\circ} \mathrm{C}$.

\begin{tabular}{ccccc}
\hline Temperature & $\begin{array}{c}\text { Ascorbic } \\
\text { acid }\end{array}$ & $\begin{array}{c}\text { Citric } \\
\text { acid }\end{array}$ & $\begin{array}{c}\text { Calcium } \\
\text { chloride }\end{array}$ & control \\
\hline $0^{\circ} \mathrm{C}$ & $2.45^{\mathrm{Aa}}$ & $3.17^{\mathrm{Ab}}$ & $2.28^{\mathrm{Aa}}$ & $2.81^{\mathrm{Aa}}$ \\
$5^{\circ} \mathrm{C}$ & $3.63^{\mathrm{Ba}}$ & $4.2^{\mathrm{Bb}}$ & $3.35^{\mathrm{Ba}}$ & $3.22^{\mathrm{Ba}}$ \\
\hline
\end{tabular}

Values followed by different superscript lowercase letters in the same row show statistically significant differences. $p=0.05$; Different superscript uppercase letters show statistically significant differences in the same column (among temperatures). $p=0.05$; Mean values. $\mathrm{N}=2$ repetitions $\times 10$ samples per repetition $=20$.

effect $(p=0.05)$ at both storage temperatures compared to other treatments. This was due to cross-linking of both cell wall and middle-lamella pectin by calcium ions [25]. The texture of a plant food is affected by the genetic background, morphology, cell turgor, water content, biochemical components and growing conditions [26,27]. Treatments with ascorbic and citric acid did not result in tissue softening, results not agreeable to those reported by Gil et al. [28]. Cocci et al. [29] showed a structural breakdown with consequent softening in apple tissue.

\subsection{Colour}

The $L^{*}$ colour value and hue angle $\left(\mathrm{h}^{\circ}\right)$ were selected as the most suitable parameters to measure the colour change of cut surface of minimally processed cabbage. When the colour became darker, a decrease in $L^{*}$ and hue angle $\left(h^{\circ}\right)$ was observed. The hue value represents true colour which is effective for visualizing the colour appearance of food products [30]. The storage time and the interaction between storage time and temperature had significant effect on $\mathrm{L}^{*}$. Among the parameters which were studied (temperature, chemical treatments, storage time and their interactions) only temperature did not have a significant effect $(p=0.05)$ on hue values.

The lightness of minimally processed cabbage decreased linearly (Figure 2) from $70.94 \pm 6$ to $63.8 \pm 8.5$ $-61.3 \pm 8$ for the chemical treatments during 22 days of 

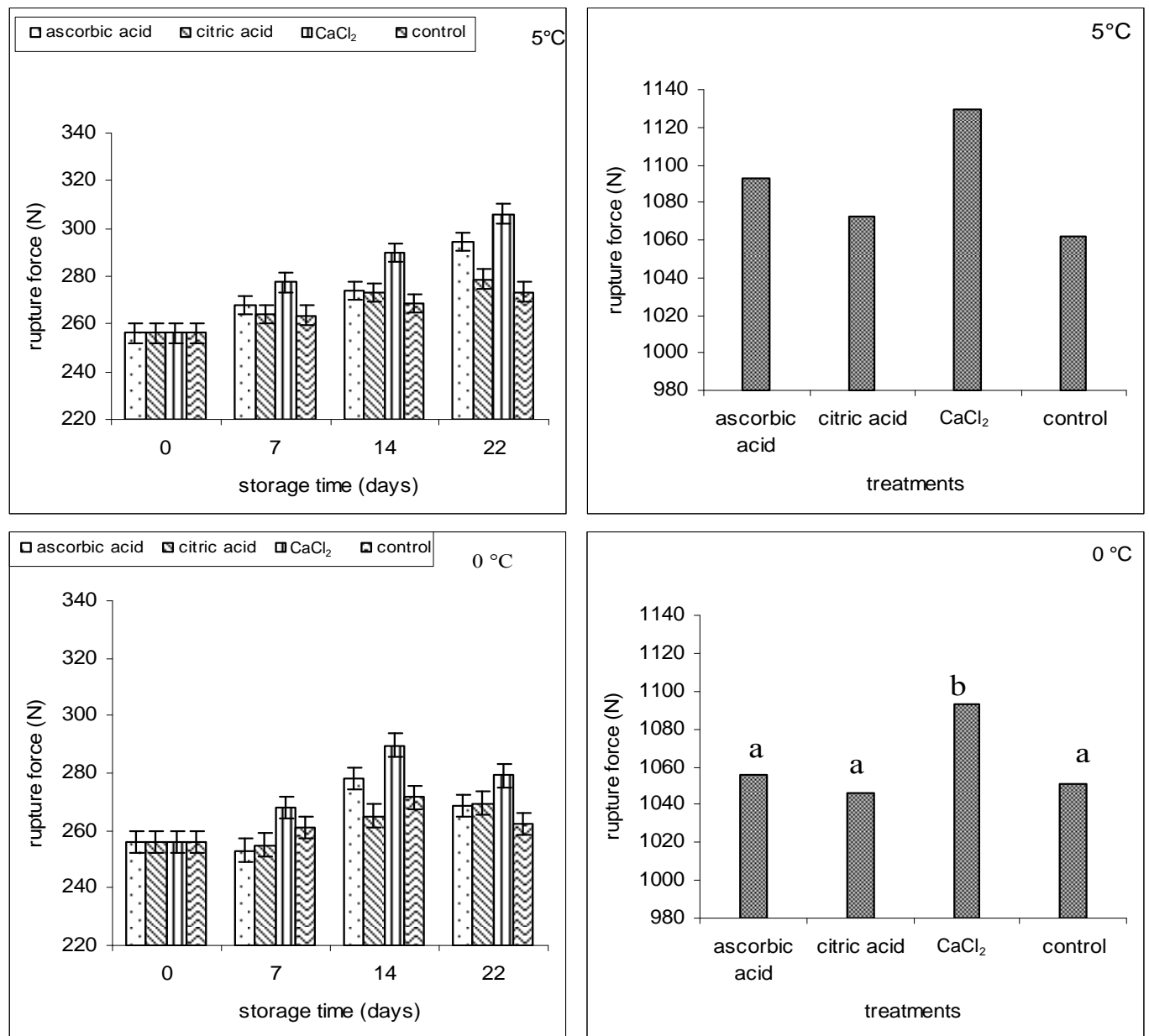

Figure 1. Effects of treatment with chemicals on the firmness of minimal processed cabbage stored at $0^{\circ} \mathrm{C}$ and $5^{\circ} \mathrm{C}$. Data observed on the left set of histograms show the changes during the 22 days of storage (Mean values. $\mathrm{N}=2$ repetitions $\times 6$ samples = 12). Vertical bars represent LSD at the $5 \%$ level. The data observed in the right set of histograms are the mean of all times.

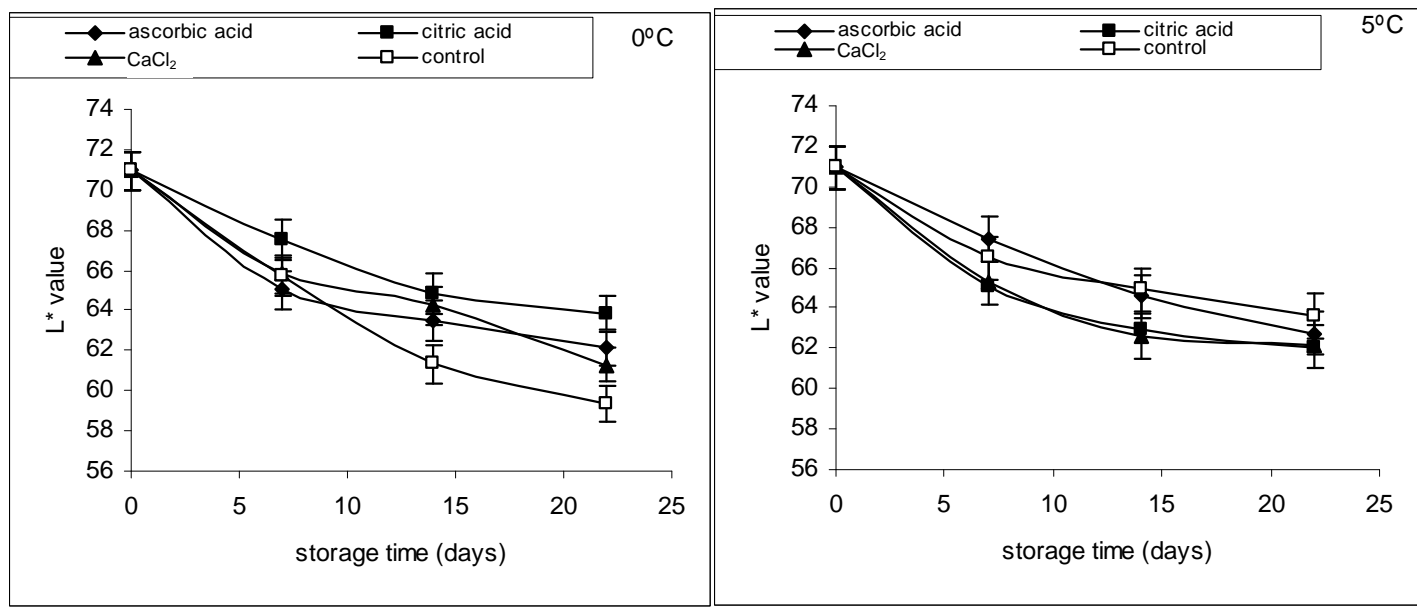

Figure 2. Effects of chemical treatments on changes in $L^{*}$ value of minimal processed cabbage stored at $0^{\circ} \mathrm{C}$ and $5^{\circ} \mathrm{C}$ for 22 days. Vertical bars represent LSD at the $5 \%$ level (Mean values. $\mathrm{N}=2$ repetitions $\times 10$ samples $=20$ ). 
storage at $0^{\circ} \mathrm{C}$. The control sample presented a decrease of $\mathrm{L}^{*}$ values to $59.4 \pm 5.4$.

At $5^{\circ} \mathrm{C}$ the lightness decreased from $70.94 \pm 6$ to 63.6 $\pm 7.9-62.07 \pm 8.2$ at all cases during 22 days of storage. By day 22 , at $0^{\circ} \mathrm{C}$ the $\mathrm{L}^{*}$ value was lower in non treated cabbage (control) than in treated cabbage with chemicals. Among the chemical treatments citric acid was the best inhibitor showing the least change in lightness. At $5^{\circ} \mathrm{C}$, no significant difference in $L^{*}$ values between the control and treated samples was observed after 22 days of storage.

Hue angle values (Figure 3) during storage time were significantly affected by chemical treatments mainly at $0^{\circ} \mathrm{C}$.

Hue angle values of control decreased rapidly at $0^{\circ} \mathrm{C}$. Among the chemical treatments, citric acid retained better the color of fresh-cut cabbage. Citric acid has been reported extensively for its inhibitory activity on polyphenol oxidase, PPO [31] and its antibrowning activity in minimally processed fruits and vegetables [32]. Our results come in agreement with Kim and Klieber [17] who worked on minimally processed Chinese cabbage and Kaur and Kapoor [33] working on minimally processed

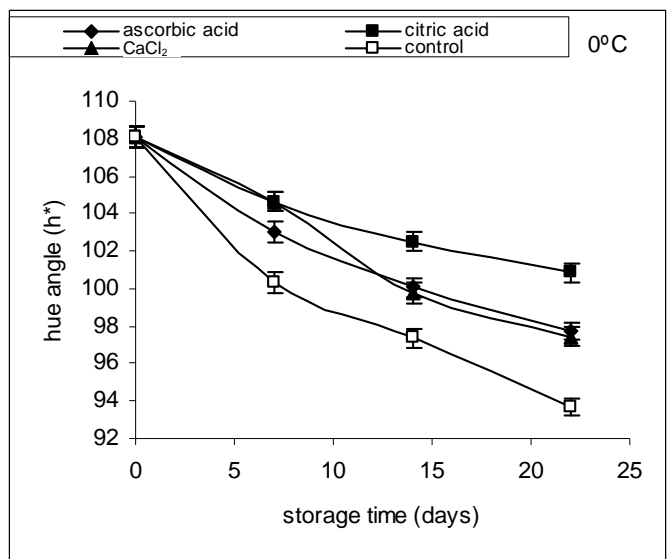

Indian cabbage. Ascorbic acid and calcium chloride are intermediate inhibitors as seen in their hue angle $\left(\mathrm{h}^{\circ}\right)$ values (Figure 3). This result was similar to results of other researchers [16,34] working on banana slices and minimally processed apples. Ascorbic acid is a reducing agent widely used as an antibrowning agent for processing of fruits and vegetables. Reductants are irreversibly oxidized during the reaction, which means that the protection they confer is only temporary since they are consumed in the reaction [34]. The action of calcium chloride might be due to the PPO inhibition by chloride ions [35].

\subsection{Soluble Solids Contents (SSC)}

The soluble solids content in minimally processed cabbage during storage at $0^{\circ} \mathrm{C}$ and $5^{\circ} \mathrm{C}$ are presented in Table 3.

At $0^{\circ} \mathrm{C}$ the control exhibited higher SSC and the cabbage treated with calcium chloride showed the smallest. At $5^{\circ} \mathrm{C}$ the treatments with ascorbic acid and citric acid exhibited the highest SSC. Similar results were reported by Jiang et al. [36] in Chinese water chestnut. Gonzalez-Aguilar et al. [37] reported an appreciable increase

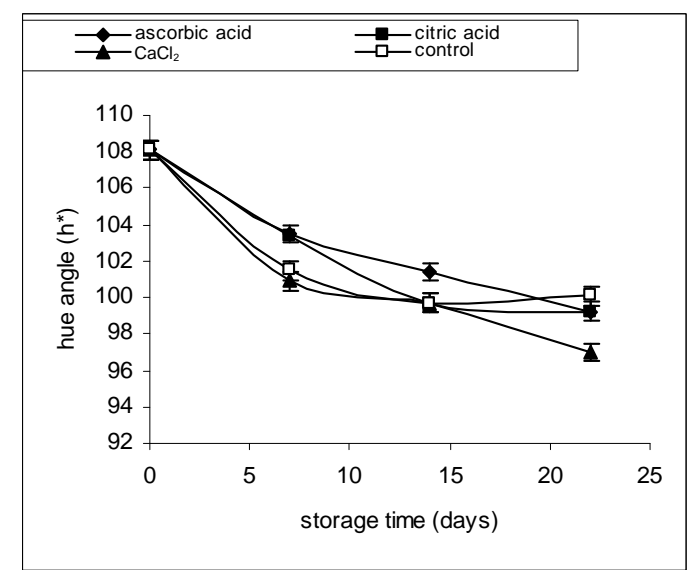

Figure 3. Hue angle changes of minimal processing cabbage stored at $0^{\circ} \mathrm{C}$ and $5^{\circ} \mathrm{C}$ for 22 days. Vertical bars represent LSD at the $5 \%$ level (Mean values. $\mathrm{N}=2$ repetitions $\times 10$ samples $=20$ ).

Table 3. Soluble solids content of minimal processed cabbage treated with different chemicals after 22 days of storage at $0^{\circ} \mathrm{C}$ and $5^{\circ} \mathrm{C}$.

\begin{tabular}{cccccc}
\hline & \multicolumn{5}{c}{ Time of storage (days) } \\
\cline { 2 - 6 } Temperature $\left({ }^{\circ} \mathbf{C}\right)$ & $\mathbf{0}$ day & Ascorbic acid & Citric acid & Calcium chloride & control \\
& & $4.5^{\mathrm{aA}}$ & $4.4^{\mathrm{aA}}$ & $4.0^{\mathrm{bA}}$ & $4.9^{\mathrm{cA}}$ \\
5 & 5.88 & $4.8^{\mathrm{aB}}$ & $4.4^{\mathrm{aA}}$ & $3.8^{\mathrm{bA}}$ & $3.9^{\mathrm{bB}}$ \\
\hline
\end{tabular}

Values followed by different superscript lowercase letters in the same row show statistically significant differences. $p=0.05$; Different superscript uppercase letters show statistically significant differences in the same column (among temperatures). $p=0.05 ;$ Mean values. $\mathrm{N}=2$ repetitions $\times 6$ samples per repetition $=$ 12. 
in fructose and glucose in fresh-cut mangoes treated with antibrowning agents and stored at $10^{\circ} \mathrm{C}$.

\subsection{Overall Organoleptic Quality}

Organoleptic quality evaluation was carried out by human volunteers in conjunction with quantifiable physical and chemical measurements to determine if a shelf-life extension treatment has merit.

Overall acceptance together with cut surface browning determined the shelf life of control samples which was 7 days at both storage temperatures (Table 4) using a score of 3 as the limit. Treatment with citric acid extended the shelf life of shredded cabbage stored at $0^{\circ} \mathrm{C}$ up to 22 days. During marketing the predominant temperature is $5^{\circ} \mathrm{C}$ and at this temperature treatment with citric acid extended the shelf life from 7 days (control) to 14 days. Ascorbic acid maintained the overall quality for 14 days at $0^{\circ} \mathrm{C}$ and 7 days at $5^{\circ} \mathrm{C}$, however, no difference was observed regarding cut surface browning compared to the control sample at both storage temperatures. Similar results were reported by Rosen and Kader [38] working with pear slices. Calcium chloride maintained the overall quality and cut surface browning for 14 days at both storage temperatures. Similar results in apples were reported by Drake and Spayed [39]. However, Bolin and Huxoll [40] reported that calcium chloride is not effecttive in preventing browning in peaches. Therefore, $1 \%$ citric acid can be used for minimally processed cabbage.

Table 4. Changes in organoleptic quality properties of minimally processed cabbage with different chemical treatments during storage at $0^{\circ} \mathrm{C}$ and $5^{\circ} \mathrm{C}$.

\begin{tabular}{|c|c|c|c|c|c|c|c|c|}
\hline \multirow{3}{*}{ Treatments } & \multicolumn{4}{|c|}{ Temperature $0^{\circ} \mathrm{C}$} & \multicolumn{4}{|c|}{ Temperature $5^{\circ} \mathrm{C}$} \\
\hline & \multicolumn{4}{|c|}{ Storage time (days) } & \multicolumn{4}{|c|}{ Storage time (days) } \\
\hline & $\mathbf{0}$ & 7 & 14 & 22 & $\mathbf{0}$ & 7 & 14 & 22 \\
\hline \multicolumn{9}{|l|}{ Overall acceptance } \\
\hline Ascorbic acid & $5^{\mathrm{aA}}$ & $4.75^{\mathrm{aA}}$ & $3.8^{\mathrm{bA}}$ & $2.1^{\mathrm{cA}}$ & $5^{\mathrm{aA}}$ & $4^{\mathrm{bA}}$ & $2^{\mathrm{cA}}$ & $1.1^{\mathrm{dA}}$ \\
\hline Citric acid & $5^{\mathrm{aA}}$ & $4.9^{\mathrm{aA}}$ & $4^{\mathrm{bA}}$ & $3.3^{\mathrm{cB}}$ & $5^{\mathrm{aA}}$ & $4.8^{\mathrm{aB}}$ & $3.3^{\mathrm{bB}}$ & $2^{\mathrm{cB}}$ \\
\hline Calcium chloride & $5^{\mathrm{aA}}$ & $4.9^{\mathrm{aA}}$ & $3.4^{\mathrm{bA}}$ & $2.1^{\mathrm{cA}}$ & $5^{\mathrm{aA}}$ & $3.4^{\mathrm{bC}}$ & $3^{\mathrm{bB}}$ & $1.13^{\mathrm{cA}}$ \\
\hline control & $5^{\mathrm{aA}}$ & $3.9^{\mathrm{bB}}$ & $2.8^{\mathrm{cB}}$ & $2.1^{\mathrm{dA}}$ & $5^{\mathrm{aA}}$ & $3.3^{\mathrm{bC}}$ & $2.4^{\mathrm{cC}}$ & $1.8^{\mathrm{dB}}$ \\
\hline \multicolumn{9}{|l|}{ Cut surface browning } \\
\hline Ascorbic acid & $5^{\mathrm{aA}}$ & $4.6^{\mathrm{aA}}$ & $2.5^{\mathrm{bA}}$ & $1.6^{\mathrm{cA}}$ & $5^{\mathrm{aA}}$ & $3.9^{\mathrm{bA}}$ & $2.5^{\mathrm{cA}}$ & $1.4^{\mathrm{dA}}$ \\
\hline Citric acid & $5^{\mathrm{aA}}$ & $4.9^{\mathrm{aB}}$ & $3.5^{\mathrm{bB}}$ & $3^{\mathrm{cB}}$ & $5^{\mathrm{aA}}$ & $4.6^{\mathrm{aB}}$ & $3.1^{\mathrm{bB}}$ & $1.8^{\mathrm{cB}}$ \\
\hline Calcium chloride & $5^{\mathrm{aA}}$ & $4.5^{\mathrm{aA}}$ & $3.5^{\mathrm{bB}}$ & $2.4^{\mathrm{cC}}$ & $5^{\mathrm{aA}}$ & $2.9^{\mathrm{bC}}$ & $3^{\mathrm{bB}}$ & $1^{\mathrm{cC}}$ \\
\hline control & $5^{\mathrm{aA}}$ & $4.4^{\mathrm{bA}}$ & $2.6^{\mathrm{bA}}$ & $2.1^{\mathrm{cC}}$ & $5^{\mathrm{aA}}$ & $3.8^{\mathrm{bA}}$ & $2.5^{\mathrm{cA}}$ & $1.8^{\mathrm{dB}}$ \\
\hline \multicolumn{9}{|l|}{ Black speck } \\
\hline Ascorbic acid & $5^{\mathrm{aA}}$ & $5^{\mathrm{aA}}$ & $2.1^{\mathrm{bA}}$ & $1.9^{\mathrm{cA}}$ & $5^{\mathrm{aA}}$ & $4.8^{\mathrm{aA}}$ & $3.3^{\mathrm{bA}}$ & $1.6^{\mathrm{cA}}$ \\
\hline Citric acid & $5^{\mathrm{aA}}$ & $5^{\mathrm{aA}}$ & $3.8^{\mathrm{bB}}$ & $3.1^{\mathrm{cB}}$ & $5^{\mathrm{aA}}$ & $5^{\mathrm{aA}}$ & $3.9^{\mathrm{bB}}$ & $2.8^{\mathrm{cB}}$ \\
\hline Calcium chloride & $5^{\mathrm{aA}}$ & $5^{\mathrm{aA}}$ & $3.3^{\mathrm{bC}}$ & $2.6^{\mathrm{cC}}$ & $5^{\mathrm{aA}}$ & $5^{\mathrm{aA}}$ & $3.1^{\mathrm{bA}}$ & $1^{\mathrm{cC}}$ \\
\hline control & $5^{\mathrm{aA}}$ & $5^{\mathrm{aA}}$ & $3^{\mathrm{bC}}$ & $2^{\mathrm{cA}}$ & $5^{\mathrm{aA}}$ & $5^{\mathrm{aA}}$ & $2.8^{\mathrm{bC}}$ & $2.3^{\mathrm{cD}}$ \\
\hline \multicolumn{9}{|l|}{ Microbial spoilage } \\
\hline Ascorbic acid & $5^{\mathrm{aA}}$ & $5^{\mathrm{aA}}$ & $3.6^{\mathrm{bA}}$ & $1.9^{\mathrm{cA}}$ & $5^{\mathrm{aA}}$ & $5^{\mathrm{aA}}$ & $3.3^{\mathrm{bA}}$ & $2^{\mathrm{cA}}$ \\
\hline Citric acid & $5^{\mathrm{aA}}$ & $5^{\mathrm{aA}}$ & $4.6^{\mathrm{bB}}$ & $3.4^{\mathrm{cB}}$ & $5^{\mathrm{aA}}$ & $5^{\mathrm{aA}}$ & $3.8^{\mathrm{bB}}$ & $3.3^{\mathrm{cB}}$ \\
\hline Calcium chloride & $5^{\mathrm{aA}}$ & $5^{\mathrm{aA}}$ & $4.1^{\mathrm{bA}}$ & $1^{\mathrm{cC}}$ & $5^{\mathrm{aA}}$ & $5^{\mathrm{aA}}$ & $3.3^{\mathrm{bA}}$ & $2.9^{\mathrm{cC}}$ \\
\hline control & $5^{\mathrm{aA}}$ & $5^{\mathrm{aA}}$ & $3.9^{\mathrm{bA}}$ & $2.8^{\mathrm{cD}}$ & $5^{\mathrm{aA}}$ & $5^{\mathrm{aA}}$ & $2.9^{\mathrm{bA}}$ & $2^{\mathrm{cA}}$ \\
\hline
\end{tabular}

Values followed by different superscript lowercase letters in the same row show statistically significant differences. $p=0.05$; Different superscript uppercase letters show statistically significant differences in the same column (among treatments). $p=0.05$; Mean values. $\mathrm{N}=2$ repetitions $\times 6$ samples per repetition $\times 6$ panellists $=72$. 
Citric acid is the most commonly used acidifier in combination with other types of antibrowning agents to control browning in fruits and vegetables.

During storage, the quality of minimally processed cabbage was affected by black speck. Black speck is a non-pathogenic disorder appearing during storage. It consists of very small to moderate size discolored lesions on the midrib and veins of the leaves [41]. At $0^{\circ} \mathrm{C}$ citric acid reduced the effects of black speck at the end of shelf-life (22 days) resulting in a better quality. Citric acid may reduce black speck through its inhibitory effect on polyphenoloxidase by lowering the $\mathrm{pH}$ and resulting in the chelation of copper at the active site of the enzyme [42]. At $5^{\circ} \mathrm{C}$ the chemical treatments affected black speck and reduced the incidence at the end of shelf-life (14 days).

Citric acid at $0^{\circ} \mathrm{C}$ and all chemical treatments at $5^{\circ} \mathrm{C}$ prevented microbial spoilage at the end of shelf-life (22 and 14 days, respectively).

\section{Conclusions}

The results presented indicate that soaking with citric acid better retains the color and the overall acceptance and organoleptic quality of fresh cut cabbage. It can reduce the cut surface browning and protect from black speck. Citric acid treatment combined with low temperature storage $\left(0^{\circ} \mathrm{C}\right)$ prolonged the shelf life of minimally processed cabbage for 22 days, time sufficient for acceptable marketing.

\section{REFERENCES}

[1] E. Watada and L. Qi, "Quality of Fresh-Cut Produce," Postharvest Biology and Technology, Vol. 15, No. 3, 1999, pp. 201-205. doi:10.1016/S0925-5214(98)00085-4

[2] D. King and H. R. Bolin, "Physiological and Microbiological Storage Stability of Minimally Processed Fruits and Vegetables," Food Technology, Vol. 43, No. 2, 1989 , pp. 132-139.

[3] J. K. Brecht, "Physiology of Lightly Processed Fruits and Vegetables," Horticultural Science, Vol. 30, No. 1, 1995, pp. 18-22.

[4] J. Zawistowshy, C. G. Biliaderis and N. A. M. Eskin, "Polyphenol Oxidase," In: D. S. Robinson and N. A. M. Eskin, Eds., Oxidative Enzymes in Foods, Elsevier, London, 1991, pp. 217-273.

[5] G. M. Sapers, "Browning of Foods: Control by Sulfites. Antioxidants and Other Means," Food Technology, Vol. 47, No. 10, 1993, pp. 75-84.

[6] M. E. Pirovani, D. R. Güemes, A. M. Piagentini and J. H Di Pentina, "Storage Quality of Minimally Processed Cabbage Packaged in Plastic Films," Journal of Food Quality, Vol. 20, No. 5, 1997, pp. 381-389. doi:10.1111/j.1745-4557.1997.tb00481.x
[7] M. Friedman, "Food Browning and Its Prevention-A Review," Journal of Agricultural and Food Chemistry, Vol. 44, No. 3, 1996, pp. 631-653. doi:10.1021/jf950394r

[8] V. M. Gomez-Lopez, P. Ragaert, V. Jeyachchandran, J. Debevere and F. Devlieghere, "Shelf-Life of Minimally Processed Lettuce and Cabbage Treated with Gaseous Chlorine Dioxide and Cysteine," International Journal of Food Microbiology, Vol. 121, No. 1, 2008, pp. 74-83. doi:10.1016/j.ijfoodmicro.2007.11.036

[9] V. M. Gomez-Lopez, P. Ragaert, J. Ryckeboer, V. Jeyachchandran, J. Debevere and F. Devlieghere, "Shelf-Life of Minimally Processed Cabbage Treated with Neutral Electrolysed Oxidizing Water and Stored under Equilibrium Modified Atmosphere," International Journal of Food Microbiology Vol. 117, No. 1, 2007, pp. 91-98. doi:10.1016/j.ijfoodmicro.2007.02.016

[10] L. D. Alvarez and A. Chiralt, "Color of Minimally Processed Fruits and Vegetables as Affected by Some Chemical and Biochemical Changes," In: S. M. Alzamora, M. S. Tapia and A. Lopez-Malo Eds., Minimally Processed Fruits and Vegetables, Aspen Publishers, Frederick, 2000, pp. 111-126.

[11] F. Pizzocaro, D. Torreggiani and G. Gilardi, "Inhibition of Apple Polyphenol Oxidase by Ascorbic Acid, Citric Acid and Sodium Chloride," Journal of Food Processing and Preservation Vol. 17, No. 1, 1993, pp. 21-30. doi:10.1111/j.1745-4549.1993.tb00223.x

[12] M. A. Rojas-Graü, Solina-Fortuny and O. Martin-Belloso, "Effect of Natural Antibrowning Agents on Color and Related Enzymes in Fresh-Cut 'Fuji' Apples as an Alternative to the Use Ascorbic Acid," Journal of Food Science, Vol. 73, 2008, pp. 267-272.

[13] Y. M. Fu, J. R. Jiang, G. Zanberman and Y. Fuchs, "Purification of Polyphenol Oxidase and the Browning Control of Litchi Fruit by Glutathiose and Citric Acid," Journal of the Science of Food and Agriculture, Vol. 79, No. 7, 1999, pp. 950-954.

[14] H. E. Moline, J. G. Buta and I. M. Newman, "Prevention of Browning of Banana Slices Using Natural Produce and Their Derivatives," Journal of Food Quality, Vol. 22, No. 5, 1999, pp. 499-511. doi:10.1111/j.1745-4557.1999.tb00181.x

[15] E. Van Rensburg and A. H. P. Engelbrecht, "Effect of Calcium Salts on Susceptibility to Browning of Avocados Fruit," Journal of Food Science, Vol. 51, No. 4, 1986, pp. 1067-1068. doi:10.1111/j.1365-2621.1986.tb11235.x

[16] P. Varela, A. Salvador and S. M. Fiszman, "The Use of Calcium Chloride in Minimally Processed Apples," European Food Research and Technology, Vol. 224, No. 4, 2007, pp. 461-467. doi:10.1007/s00217-006-0344-7

[17] S. Kim and A. Klieber, "Quality Maintenance of Minimally Processed Chinese Cabbage with Low Temperature and Citric Acid Dip," Journal of the Science of Food and Agriculture, Vol. 75, No. 1, 1997, pp. 31-36. doi:10.1002/(SICI)1097-0010(199709)75:1<31::AID-JSF A836>3.0.CO;2-X 
[18] Y. F. Chu, J. Sun, X. Wu and R. H. Liu, "Antioxidant and Anti Proliferative Activities of Common Vegetables," Journal of Agricultural and Food Chemistry, Vol. 50, No. 23, 2002, pp. 6910-6916. doi:10.1021/jf020665f

[19] Y. S. Keum, W. S. Jeong and A. N. T. Kong, "Chemoprevention by Isothiocyanates and Their Underlying Molecular Signalling Mechanisms," Mutation Research, Vol. 555, No. 1-2, 2004, pp. 191-202. doi:10.1016/j.mrfmmm.2004.05.024

[20] M. M. Rinaldi, B. C. Benedetti and C. L. Moretti, "Respiration Rate, Ethylene Production and Shelf Life of Minimally Processed Cabbage under Controlled Atmosphere," Acta Horticulturae, Vol. 876, 2010a, pp. 279286.

[21] M. M. Rinaldi, C. I. G. L. Sarantopoulos, B. C. Benedetti and C. L. Moretti, "Storage of Minimally Processed Cabbage in Different Packaging Systems," Acta Horticulturae, Vol. 877, 2010b, pp. 597-602.

[22] M. C. Gacula and J. Singh, "Statistical Methods in Food and Consumer Research," Academic Press Inc., New York, 1984

[23] S. J. Kays, "Postharvest Physiology of Perishable Plant Products," AVI Publisher, New York, 1991, pp. 356-357.

[24] H. M. Kang, K. W. Park and M. E. Saltveit, "Elevated Growing Temperatures during the Day Improve the Postharvest Chilling Tolerance of Greenhouse-Grown $\mathrm{Cu}-$ cumber," Postharvest Biology and Technology Vol. 24, 2002, pp. 49-57. doi:10.1016/S0925-5214(01)00129-6

[25] W. Poovaich, "Role of Calcium in Prolonging Storage Life of Fruits and Vegetables," Food Technology, Vol. 40, No. 5, 1986, pp. 86-89.

[26] F. R. Harker, R. J. Redgwell, I. C Hallet and S. H. Murray, "Texture of Fresh Fruit," Horticultural Reviews, Vol. 20, 1997, pp. 121-224.

[27] E. Sams, "Preharvest Factors Affecting Postharvest Texture," Postharvest Biology and Technology, Vol. 15, No. 3, 1999, pp. 249-254. doi:10.1016/S0925-5214(98)00098-2

[28] M. I. Gil, J. R. Gorny and A. A. Kader, "Responses of 'Fuji' Apple Slices to Ascorbic Acid Treatments and Low Oxygen Atmospheres," Horticultural Science, Vol. 33, No. 2, 1998, pp. 305-309.

[29] Cocci, P. Rocculi, S. Romani and M. Dalla Rosa, "Changes in Nutritional Properties of Minimally Processed Apples during Storage," Postharvest Biology and Technology, Vol. 39, No. 3, 2006, pp. 265-271. doi:10.1016/j.postharvbio.2005.12.001

[30] R. G. Mcguire, "Reporting of Objective Colour Measurements," Horticultural Science, Vol. 27, No. 12, 1992, pp. 1254-1255.

[31] T. T. Langdon, "Preventing of Browning in Fresh Pre- pared Potatoes without the Use of Sulfiting Agents," Food Technology, Vol. 41, No. 64, 1987, pp. 66-67.

[32] R. Ahvenainen, "New Approaches in Improving the Shelf Life of Minimally Processed Fruit and Vegetables,". Trends in Food Science and Technology, Vol. 7, No. 6, 1996, pp. 179-187. doi:10.1016/0924-2244(96)10022-4

[33] C. Kaur and H. C. Kapoor, "Antioxidant Activity and Quality of Minimally Processed Indian Cabbage (Brassica Oleracea var. Capitata)," Journal of Food Processing and Preservation, Vol. 25, No. 5, 2001, pp. 367-380. doi:10.1111/j.1745-4549.2001.tb00467.x

[34] M. Apintanapong, K. Cheachumluang, P. Suansawan and N. Thongpraset, "Effect of Antibrowning Agents on Banana Slices and Vacuum-Fried Slices," Journal of Food Agriculture and Environment, Vol. 5, No. 3-4, 2007, pp. 151-157.

[35] Garcia and D. M. Barette, "Preservation Treatments for Fresh Cut Fruits and Vegetables," In: O. Lamikanra, Ed., Fresh Cut Fruits and Vegetables: Science, Technology and Market, CRC Press, Boca Raton, 2002, pp. 267-303.

[36] Y. M. Jiang, L. T. Peng and J. R. Li, "Use of Citric Acid for Shelf Life and Quality Maintenance of Fresh-Cut Chinese Water Chestnut," Journal of Food Engineering, Vol. 63, No. 3, 2004, pp. 325-328. doi:10.1016/j.jfoodeng.2003.08.004

[37] A. Gonzalez-Aguilar, C. Y. Wang and J. C. Buta, "Maintaining Quality of Fresh-Cut Mangoes Using Antibrowning Agents and Modified Atmosphere Packaging," Journal of Agricultural and Food Chemistry, Vol. 48, No. 9, 2000, pp. 4204-4208. doi:10.1021/jf991384j

[38] J. C. Rosen and A. A. Kader, "Postharvest Physiology and Quality Maintenance of Sliced Pear and Strawberry Fruits," Journal of Food Science, Vol. 54, No. 3, 1989, pp. 656-659. doi:10.1111/j.1365-2621.1989.tb04675.x

[39] S. R. Drake and S. E. Spayed, "Influence of Calcium Treatment on 'Golden Delicious' Apple Quality," Journal of Food Science, Vol. 48, No. 2, 1983, pp. 403-405. doi:10.1111/j.1365-2621.1983.tb10752.x

[40] R. Bolin and C. C Huxoll, "Storage Stability of Minimally Processed Fruits," Journal of Food Processing and Preservation, Vol. 31, No. 4, 1989, pp. 281-292. doi:10.1111/j.1745-4549.1989.tb00107.x

[41] R. Walsh, E. C. Lougheed and P. M. A. Toivenon, "The Effect of Benomyl. Sodium Hypochlorite and Controlled Atmospheres upon the Incidence of Black Speck of Stored Cabbage," Journal of American Society of Horticultural Sciences, Vol. 108, No. 4, 1983, pp. 533-536.

[42] R. Lyengar and A. J. Mcevily, "Anti-Browning Agents: Alternatives to the Use of Sulfites in Foods," Trends in Food Science and Technology, Vol. 3, 1992, pp. 60-64. doi:10.1016/0924-2244(92)90131-F 